\title{
Vital minimums: El Salvador between youth and old age
}

\author{
Jorge E. Cuéllar ${ }^{1}$
}

Accepted: 28 September 2021 / Published online: 3 November 2021

(c) The Author(s), under exclusive licence to Springer Nature Limited 2021

\begin{abstract}
Through the concept of the "vital minimum"- the notion of basic life rights and living standards for all Salvadorans articulated by the early twentieth-century Salvadoran essayist Alberto Masferrer-this essay demonstrates the importance of older adult sociality and old age return as a prism through which to understand contemporary El Salvador. Examining retiree objectives and everyday practices among older Salvadorans in a transnational frame, the article links Masferrer's vitalist thinking to mounting concerns of older adult dignity and the coming general crisis of care as the Salvadoran population uptrends toward older age. The article suggests the need to take stock, politically and analytically, of the social worlds shaped and bolstered by older adults, underscoring their roles as economic supports, community mediators, and caregivers, which make possible the social reproduction of community itself.
\end{abstract}

Keywords Older adulthood $\cdot$ Transnational $\cdot$ Dignity $\cdot$ Care $\cdot$ Retirement $\cdot$ Aging

\section{Mínimos vitales: El Salvador entre la juventud y la vejez}

\section{Resumen}

Partiendo del concepto de "mínimo vital", la noción de los derechos humanos básicos y los estándares de vida para todos los salvadoreños según articulada por el ensayista salvadoreño de principios del siglo veinte Alberto Masferrer, este ensayo demuestra la importancia de la sociabilidad para los adultos mayores y del regreso al país en la vejez como prisma a través del cual entender a El Salvador contemporáneo. Al examinar los objetivos de jubilación y las prácticas cotidianas entre los salvadoreños mayores dentro de un marco transnacional, el artículo vincula el pensamiento vitalista de Masferrer con las inquietudes cada vez mayores sobre la dignidad en la vejez y la crisis general de atención médica que se avecina con la tendencia en alza

Jorge E. Cuéllar

jorge.cuellar@dartmouth.edu

1 Dartmouth College, Hanover, NH, USA

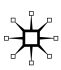


en la edad de la población salvadoreña. El artículo sugiere la necesidad de evaluar, política y analíticamente, los mundos sociales formados y sostenidos por los adultos mayores, enfatizando sus funciones de sostén económico, mediadores comunitarios y cuidadores, las cuales posibilitan la reproducción social de la comunidad misma.

Palabras clave Adultez mayor · Transnacional · Dignidad · Cuidado · Jubilación · Envejecimiento

On December 25, 2015, my parents "repatriated" to their native El Salvador after more than two decades of living in the United States. They left Los Angeles to retire to a country that, in the month they departed, held the unenvious title of being the undisputed homicide capital of the world (Marroquín 2015). At first, I thought moving back to El Salvador made little sense, as news from the region painted a situation of social impossibility, where huge swaths of the population instead moved in the opposite direction, to make "good lives" in the United States and Canada, to gamble on the dice roll of asylum and refuge. Unlike my parents, today's migrantsthose physically able to make the grueling trek northward in treacherous and militarized conditions-flee inhospitable realities: extreme levels of violence, economic abandonment, food insecurity, gender discrimination, and climate vulnerability, all legacies of US policy promotion and development. War and postwar migration have taken similar routes, but ongoing escape from contemporary Central America is but a morbid symptom of the multigenerational foreclosure of dignified living. After the much-covered "unaccompanied minors' crisis" of 2014, the following year marked an equally concerning statistical peak for forcefully displaced persons seeking access to northern nations (Park 2014). Given this context, repatriation-in this case older adult return-was then, and remains, difficult to substantiate as Central America spirals further into social and economic ruin.

In a reality overdetermined by homicide statistics and endemic poverty, what possibilities does a country like El Salvador offer to the now-aging person, to the transnational retiree? Thinking with and extending concepts developed by the influential Alberto Masferrer (1868-1932), the early twentieth-century Salvadoran essayist, autodidact, and critic, this essay attends to the contemporary social life of older age, the possibilities of making a fulfilling life in El Salvador in retirement. Thinking across El Salvador and the United States, I focus on the rationales and experiences lived by a disperse group of older Salvadorans in western El Salvador that have chosen to repatriate back to the home country, opting to return to contexts depicted by chaos, strife, and pervasive political senselessness. It is worth noting that this is a phenomenon dependent on specific family economic outcomes, as well as placebased specificity in the United States, where, in some cases, Salvadoran families simply move from expensive metropolitan areas to rural locations, or increasingly, toward affordable living found across the Midwest. Eschewing a totalizing view of Salvadoran old age experience, or even late-life migration outcomes, this essay instead attends to a selection of experiences accessed through my own familial connections and friendships, yet that remain anonymous as a matter of subject safety. 
Relying on observations with family and neighborhoods linked to relatives across El Salvador, I experiment with concepts forged by Masferrer as they pertain to notions of old age well-being. Building from personal experience and moving across Salvadoran territory relying on informal interviews that sometimes doubled as oral histories, I offer a reading of El Salvador through the oft-neglected optic of older adulthood as age-specific social analysis, reframing Masferrer as an intellectual origin point from which to begin an analysis of Salvadoran everyday life. To recover Masferrer's work, I situate his life and thinking for wider readerships, proposing a critical revisit to his central idea-the notion of the "vital minimum" first published in 1929-as a concept useful to understand the meanings of old age repatriation and transnational return to a region whose cruelty and perceived unlivability continues to be its dominant feature (Franco 2013). The old, whose exact age is treated in relative terms, is understood here as persons who reach administrative retirement, which in the United States and El Salvador is approximately sixty to sixty-five years old, wherein people age into "retiree," senior, or pensionado statuses. The turn to Masferrer, now evidently anachronistic, is an attempt to develop a country-specific analytic grounded in local intellectual traditions, to test its utility for thinking contemporary social problems. In this respect, this essay is an experiment in theory, in deploying place-based thought for examining local specificities and concerns, using homegrown instruments to attend the peculiar historicity of social dynamics.

First, this essay situates the vital minimum in early twentieth-century El Salvador alongside the philosophical currents, racial discourses, and the limitations of elite-led national projects that crisscrossed the region in the decade leading to the global capitalist crisis of the late 1920s. This historical and intellectual background, which is also the trajectory of Salvadoran liberalism, is important for explaining the conditions that motivated Masferrer's thought, and how he remains central to contemporary Salvadoran imaginaries (Racine 1997, p. 236). This is also significant given Masferrer's limited reach and largely unknown status among English-speaking scholars, including Latin American and Latinx audiences. Appraising his thinking within his lifetime will help demonstrate its analytical reach for our more present concerns. The essay offers a brief intellectual excavation to elaborate how his concept (bracketing its later appropriations) should be thought of as a precursor to more modern ideas of social security, or the "living wage." Traversing the literary and historical context that produces Masferrerian thought and its enshrining in Salvadoran intellectualism, I read the "vital minimum" as a possible theory for understanding the relation between age, society, and well-being. Second, addressing issues affecting older adult and retiree communities specifically, I recast the vital minimum as a starting point for a working concept of old age dignity, wherein contexts of coming demographic transition in the region will require a framework capable in making sense of, culturally and politically, an aging Salvadoran society (Córdova et al. 2010; Tablas 2012; Aranco et al. 2018, p. 8).

Subsequently, via case study, I turn to the worlds of older Salvadorans who choose to repatriate. I offer in-country descriptions, impressions of everyday life, and short narrative examples to suggest that retiree return is a late-stage strategy in pursuit of belonging, sociality, and kinship increasingly unavailable in "destination" countries. My approach, admittedly, does not offer systematicity nor a society-wide 
thesis of older adulthood. Although home country aging is, for some repatriating retirees, a search for a comfortable late life, one that is paradoxically facilitated in El Salvador and seemingly difficult in the United States, this is not the case for all. The families I refer to throughout depart the United States for El Salvador from metropolitan areas like Los Angeles, Houston, San Francisco, unwilling to move to "cheaper" parts of the US. These are lives produced by endless variables and personal idiosyncrasies. Nevertheless, the aggregate sense I arrive at, beamed through the vital minimum, is that many of these late-stage moves, in the twenty-teens, are driven by mounting anti-immigrant and anti-Latino racism, the legal and economic shrinking of belonging, exploding living and care costs, and the perceived US culture of "throwing away" unproductive populations (Thelen and Coe 2017; Morris and Bass 1986).

Hereafter, I offer an account of Salvadoran transnational aging gleaned from informal conversations and embedded observation with family, primarily, as well as older adult friends and neighbors during my in-country field research in 2015 and 2016, near the town of San Martín, western El Salvador, and its surround. More specifically, I rely on impressions from relatives and community members, as well as my long-term personal observation of the social habits of older adults, refracting these perceptions through Masferrerian ideas of well-being. Here I identify and interpret the habits and practices of older adults as evidence of a unique form of agency and sociality - a habitus - that is, notwithstanding poverty and social enclosure, a force that produces a sense of dignity for people that can counter the expected effects of life-course decline and old age fatigue. Retirees coming from abroad can, with added benefits, tend for themselves, access medicine and care treatment. and obtain extended support from local community and transnational socioeconomic relations. As El Salvador continues to be enveloped in a youth crisis driven by antisocial stereotyping, late-stage aging situates persons into spaces where prosocial activities might develop and prolong old adult utility. This, in turn, provides evidence of - if budding-late-life forms of agency that enable dignified forms of social participation that incorporate evergreen skill sets, insights, and able-bodiedness. The age-specific crisis that circumscribes El Salvador's social world today has contrary to popular wisdom, also generated important openings, roles, and space for older persons that, despite their centrality to familial life, routinely go unremarked, in contrast to the oft-repeated tropes of enfeeblement and of being socially unproductive, household inconveniences, or burdensome dependents. The humble objective here is to emphasize that older persons, in addition to having divergent outcomes, are essential to reproducing the social itself, and that in the Salvadoran context, older adulthood affords a degree of autonomy and mobility for practicing self-reliance - a kind of vital minimum in the Masferrerian sense-despite the country's frenzied homicidal ecology (Yashar 2018).

Though exceeding the scope of the present essay, Masferrer's ideas and legacies remain complex and contested. Yet despite these imperfections, they retain a sociohistorical and cultural specificity - and an unusual in-country relevance-that make them pertinent for examining the polarities of the contemporary Salvadoran crisis: age. The vital minimum as a concept, then, when considered with similar ideations such as the minimum wage of the worker's movement, the solidarity, just or 
living wage, Indigenous notions of buen vivir, and other forms of collective and just remuneration that demand inalienable rights to a dignified life, can offer a capacious analytic for thinking across age — from youth to older adulthood-to theorize and gauge the central axis, the age-old and age-related contradictions around care, life, and its supports, on which the generalized and longue durée Salvadoran crisis turns. Masferrer is an exemplary intellectual pivot for this conversation attributable to his numerous writings and reflections that sought, tirelessly, to examine the character and shape of Salvadoran sociality.

\section{A philosophy of life}

What is the vital minimum? The concept of the "vital minimum" is a theory of needs formulated by the Salvadoran political essayist Alberto Masferrer, who first expressed the idea as a metric for remedying economic inequality. As a social doctrine, it sought to curtail the excesses of the brutal child labor regimes that characterized agrarian exploitation of the poor and racialized underclasses in the brutal coffee economy at the turn of the twentieth century (Masferrer 1996). Masferrer was important to both literary and political publics of his time and, in addition to his holding state posts, helped spark debate around vitalism as a social philosophy that might have productive application in humanizing elite rule in the country and relieve the exploitation of the immiserated masses abused by the coffee oligarchy and a militarist state (Ching 2014). Competing versions and appropriations of Masferrer endure to the present, and his writings have proven long-lasting; he remains a permanent fixture of official culture alongside "national" figures such as Óscar Romero. Like the archbishop-turned-saint, Masferrer's name adorns institutions such as universities, colleges, grade schools, and roadways, his tomb now decreed cultural patrimony. These are signs of the continued relevance of a national figure who passionately, if shortsightedly, identified social problems and advocated for a more egalitarian world in an El Salvador at the height of planter capitalism, on the eve of one of the bloodiest campesino-Indigenous massacres in the Americas, which an old Alberto Masferrer would publicly denounce, contrary to the silence of his contemporaries (Lara-Martínez 2011, pp. 95, 104-105; Cuéllar 2018).

As Central America weathered political unrest and protracted economic depression, Masferrer launched a scathing critique of the Salvadoran state and the reigning political classes for effectively abandoning the youth, for failing to equip them with the tools needed to improve their lives and thus the life of the country. Commenting on Masferrer's early Niñerias (1916), the Salvadoran writer Ítalo López Vallecillos powerfully penned that Masferrer's interventions and critiques "made comprehensible the inertia of oppression that deforms social reality" (Lopez Vallecillos 1968, p. 16). Masferrer's analysis of poor governance was aimed, ultimately, at reforming state services, to improve public institutions especially in the realms of education and health care that, in his view, were central to the malformation of youth in his time (Guerra Reyes 2014). While Masferrer's concerns responded to youth disenfranchisement and to resolving long-standing issues in "social development," his thinking was, above all, a deeply humanist engagement with the realities faced by 
Salvadoran people of all ages confined to a system of expanding social inequality, in which children and youth both lived and labored. Realizing this, Masferrer wrote, "our children can be, for us, instruments of condemnation or instruments of life" (Masferrer 1947, p. 60). For the writer, these instruments-youth-needed to be shaped and molded into positive agents to ensure a harmonious society that prioritized, if now problematic, the traditional notions of family, harmonious community, and national welfare.

Masferrer's thinking on old age is not formally delineated in his writings, as are his expansive notes on youth, but I derive them from his broader theorizing of the vital minimum as refracted through his personal experiences of life-long illnesses such as tuberculosis, pneumonia, syphilis, and cardiovascular irregularities, until his death at age sixty-four. Masferrer's life, in one sense, tracks the life-course experience of an older Salvadoran adult in the early twentieth century. I suggest that his experiences infuse the "vital minimum" as a notion, which is already a puzzlingly syncretic and composite formulation, that integrates the life philosophies of Asia and Europe, both incorporating and at times exceeding the reigning positivisms and Marxisms of the time. The literary scholar Marta Elena Casaús Arzú notes that the heterodox Masferrer also borrowed from Fabian socialism, anarchism, and unionism, which makes his vitalismo, his thinking, difficult to systematize, making it appear contradictory over time (Casaús Arzú 2011, p. 105). As a concept, however, the vital minimum is a holistic idea, one linked closely to the social democratic tradition, spiritualism, and the Hispanisms - both derived yet contested - that dominated intellectual circles of early twentieth-century Central America and that, shortsightedly, imagined the region as capable of overcoming its endemic failings via liberal parliamentarianism, using institutional avenues to rectify extreme inequality caused by wealth polarization, fixed racial hierarchy, and festering class enmity (Casaús Arzú 2009a).

The vital minimum, in its most politically active form, was a moralistic discourse to draw attention to the necessity of social guarantees to housing, food, water, work, justice, and education (Masferrer 1996; Racine 1997, pp. 211-212). It is, in my reading, the Masferrerian conception of "dignity," which draws on 1920s-era liberalprogressive values. Masferrer's positions, unlike those of other period intellectuals, stood apart from eugenicist versions typical of Latin America at the time, such as in the reductive social Darwinisms that became de facto national ideology in neighboring Guatemala (Grandin 2000, p. 148). Instead, Masferrer's vitalism and public writings unequivocally advocated for the participation of women and Indigenous persons in politics - most notably the feminist forerunner Prudencia Ayala, the first woman, and of Afro-Indigenous descent, to run for president in El Salvador and in all of Latin America- believing women and racial others to be fundamental to forging an improved national culture and renewed political institutions. This position was a clear deviation from era race-thinking enclosed by the naturalized connection with "race" to "degeneration," invariably seduced and rationalized by a totalizing mestizaje (Casaús Arzú 2009b, pp. 128-130).

For Masferrer, the "vital minimum" was a concrete vision of social egalitarianism akin to utopian socialism, one that in his optimistic view appeared possible, given the structural conditions of El Salvador, and that would, in an immediate sense, 
lessen the suffering of his compatriots, those exploited by an unjust economic system. Thus, given its centrality to Salvadoran thought, Masferrer's polyvalent conception remains an important "life philosophy" of peculiar applicability to El Salvador (Casaús Arzú and Fuentes 2012). As part of intellectual history, the concept grew from a truncated social democratic outlook that, in deviating from politics as usual, demanded and defended the fundamental rights to collective well-being of disenfranchised nominal groups, from within the parameters of liberal modernity. Masferrerian thought, as noted by Salvadoran scholars, drew attention to age-specific living in El Salvador, starting with children, to youth and into adulthood, placing dignity and well-being as the root criteria of a good, comfortable, and satisfying life (Aparicio 2007, p. 66; Alemán 2017; Introvigne 2016). To this day, Masferrer's image and work retains much relevance in Salvadoran everyday life and intellectual culture - from pedagogy to public art-his legacy, controversial and a site for debate, remains part of the educational and historical fabric of the country (Guerra Reyes 2015).

\section{The contemporary Masferrer}

In the post-1992 era, some sixty years after Masferrer's death, El Salvador remains a country not much different than the one in which he lived. In fact, the issues that Masferrer identified-economic polarization, military authoritarianism, a refusal of agrarian reform - by the late 1970s had reached suffocating levels that, arguably, precipitated the 1980s internal conflict (Wood 2003). The Salvadoran Civil War that lasted from 1980 to 1992 also produced many of today's contradictions related to late-life care. Notably, it created a whole class of neglected ex-combatants, a classwide abandonment of veteran groups that accelerated as the country turned toward neoliberalism. This rapid turn also equated to the compression of wages and reduced medical and retirement benefits that, in many cases, eliminated pensions entirely. El Salvador emerged from its war as a country still mired by inequality, exploitation, and eroding social welfare. Given these enduring economic antagonisms that track throughout the twentieth century, Masferrer's formulations on youth, on social decline, and on well-being maintain a relevance to recurring age-related crises that are now, again, bursting onto national politics. Malformed youth who once stood for national underdevelopment for Masferrer, symbols of rampant poverty and malnutrition (Briggs 2003), became over time, reimagined as the "at-risk" youth in neoliberal Central America. Youth in the region persist as suspicious and criminal figures, viewed as a malignant social disease (Levenson 2013). Older adults, who in a different moment naturally became role models and wellsprings of local wisdom, are now-because of unchanging economic inequality and exploitative labor arrangements - reduced to economic dependents of ever-struggling families. Older people are, still, despite emotional ties, largely viewed as unproductive or a drain on resources, time, and labor as older adult maintenance needs increase.

Unlike transnational retirees, whose well-being is supplemented by pensions from abroad or by family remittances, for those in-country nationals entering retirement age (of which war veterans form part), the question of late-stage 
dignified living is a complicated, highly stressful problem with little reprieve. For veterans of the Salvadoran Civil War, once-warring factions now organize protests to coax improved state benefits, marching to remain part of yearly national budgets. As of 2019, ex-military and ex-guerrilla veterans receive a meager $\$ 100$ as monthly pension (Pacheco 2019), whereas retirees coming from the US receive substantially more. For decades, protesting together, veteran factions have highlighted the failures of the Salvadoran pension system and demanded the provision of a living wage along with benefits such as housing assistance, food grants, and health services to attend the needs, the vital minimums, of more than 94,000 surviving veterans (Associated Press 2016; Wiegink and Sprenkels 2020). As a matter of political economy, pensions have been used by governments for country debt restructuring, by cutting benefit disbursements or making eligibility criteria impossible, placed behind changing requirements, proofs, and new stipulations. The Salvadoran pension system also disqualifies informal laborers from attaining benefits and excludes this popular sector from obtaining retiree support, which effectively leaves many older adults, who spent their work life in the informal economy, derelict and dependent on passerby charity or on neighborly aid (Villalona 2005). As the struggle against the privatized pension system reveals, old age care in El Salvador is a multisectoral issue that connects veteran rights to the needs of aging workers, to the future retirement prospects of the present and future old.

The dignity struggles affecting old age Salvadorans require we analyze the cultural and social needs of older adults across the life course. The vital minimum is useful for this objective. As part of a renewed social contract in the early 1920s, the vital minimum was, for the liberal Masferrer, a flexible and adaptable metric that could serve the goal of establishing generalized rights to well-being, welfare. The "vital minimum" was, for Masferrer, "despite being voluntarily restricted and content with satisfying basic needs..., above all a living thing, whose finality is life, whose spring and path is life itself" (Masferrer 1996, p. 77). This organic philosophy that doubled as a politics attempted to place life as its operative notion. It sought to center caretaking of life as itself a sociality: from older adults to trees to supporting the work of orphanages, asylums, and other institutions of care that shape society and its individuals. Indeed, one of Masferrer's major dictums in his Mínimum Vital (1929) was, "Help all of your children, your elder parents, and the needy" (Masferrer 1996, p. 78). Masferrer's articulation, despite its laudable social progressivism is accurately critiqued in the matter of Masferrer's authorial subjectivity, which reproduced blind spots that were all too common to this generation of elite literati who veered toward a conservative Catholic humanism as a strategy to persuade the powerful. Masferrer is archetypal of early twentieth-century Central American appeals to elite morality intent on influencing local rule to grant labor rights, wage increases, and the like to popular sectors. This, from Masferrer's view, was articulated-in his role as a public intellectual-to alleviate the misery of workers and their families (Racine 1997, pp. 236-237). Recent writers note that his thinking was a product of a white, literate, masculine, privileged subjectivity and was thus handicapped by his very social position. In this way, contemporary critics of Masferrer stress his limitations to authentically narrating the nation and its problems, unable to move 
beyond hopes of social harmony despite solidified racial antagonisms and class cleavages (Lara-Martínez 2017).

Vitalist thinking is often viewed as naïve and elite-driven, failing to expound a concrete radical politics, or inadequate in the jettisoning of mestizaje discourse, incapable of shedding its bourgeois nationalism or the erroneous biologisms of the period. Materially, The Vital Minimum and Masferrer's writings are indeed a product of an early 1900s political and cultural matrix. They should, of course, not be fully untethered from their milieu, nor should they be engaged as crassly transposed. My rethinking in this essay, while cognizant of its origins and the general discrediting of vitalism as social theory, is geared at distilling the useful parts of the vital minimum as a concept and form, as a way of seeing social problems that might, in turn, prove helpful to examining life-making possibilities in twenty-first-century El Salvador as per age and age-specific living. By recasting the vital minimum through Masferrer's work on youth, well-being, and older adulthood, I read it not as a comprehensive theory of society but rather as a fragmentary and diffuse theory of needs that focuses on age as a primary quality for exploring largely unexamined phenomena: transnational retiree mobility and older adult survival strategies. This, I contend, helps us to arrive at a fuller account of a shifting and contested Salvadoran social formation.

\section{The sociality of age in El Salvador}

In a country enveloped by youth gang crises, able-bodied older adults still take part in meaningful social experiences that, in many cases, are risk-laden for young adults and adolescents. As I observed in San Martín, El Salvador, the act of visiting friends and family in a neighboring canton when it is controlled by rival gangs can prove deadly. This is especially true for youth, who are profiled as suspicious, overpoliced, or misrecognized as gang-affiliated. In a context of generalized gang rule, older persons can exert social agency in ways that bolster community and that provide support to maintaining social relations across neighborhoods. As I documented via multiple research trips in 2015-2016, older adult habits and mobility practiceswalking and riding the bus to church, to shop, visit with people-have an arrhythmic relation to the very same spaces traversed by youth or those in middle adulthood, who might still be suspiciously profiled. In hotspots of gang activity, such as in the networked backroads that compose San Martín and Ilopango, for instance, where gang density is high and neighboring hamlets are controlled by rival cliques, older persons appear to maneuver smoothly through conflict-ridden environments, often tasked with doing out-of-home activities and running errands for households. On more than one occasion, I observed older adults shuttling groceries to their homes, catching the bus to go pick up children from school, bringing food to neighbors, or selling bread, soup, tortillas, for lunch and early dinners. Further, I observed how, methodically, older adults visited friends and family after dark, worshipped until late hours, often delivered home-cooked meals to others, brought their shucked corn to the local mill for grinding into tortilla flour, or sold prepared food to other families - all while bypassing gang-affiliated lookouts, usually young men and boys standing vigilant at neighborhood entrances with weapons in tow. Within families, 
older adults might also be tasked with child-rearing duties, serving as unreliable disciplinarians to youth or as watchful eyes to children playing in alleys, kicking the football on a dusty dirt patch. Across these sites, older adults performed socially reproductive activities and minor entrepreneurship, trading homemade items for quarters and dollars.

In the marketplaces of historic San Salvador, too, older adults function as effective mediators for dispute resolution and are, from the standpoint of those involved with pandillas, perceptibly nonaffiliated, neutral, ordinary community members. Although older people generally remain on the margins of gang activity, if they are dealing in sales transactions, they will likely interface with gangs by paying extortion to them to ensure "security" and tranquility. Older adults can help navigate a complex and insecure landscape, mobilizing their age to reduce personal risk. Although my observations are not generalizable, what is evident is that, in low-wage El Salvador, still-mobile older adults take on familial risk, doubling as unexpected lifelines by shouldering tasks of critical import, inside and outside of the home. From errand-running to food preparation to providing a source of supplemental income, older adults continue to contribute. The roles played by older persons are, in these contexts, vital to the survival of neighborhoods, as members perform intermittent work as vendors, traveling salespeople, messengers, observers, food makers, and as informants to others of goings-on. Older adults add to the economics of the home, helping sustain neighborhood coherence as gang-police dynamics foment displacement and fragmentation. Within marginalized environs, older persons are able providers to a household's vital minimum: via economics, care work, food preparation, safety, contributing to the material and emotional well-being of family and, by extension, their canton.

In San Salvador, like in other popular economies that dot the Latin American streetscape, vendors and panhandlers in open-air markets are often older adults or persons with disabilities, sometimes both. The unemployed or underemployed older adult, defined in Salvadoran law as those above sixty years old for men and fiftyfive for women, can be usually found, if not selling goods for their own subsistence, then nearby assisting relatives in handling the responsibilities of the stand, either helping customers or doing quick errands in the marketplace. During my time spent in Salvadoran markets across San Salvador and in other populous towns like San Martín and Soyapango, I quickly recognized how older persons take up key roles at vendor stands, roam around selling candies or cigarettes, or help fellow salespersons in cleanup work and maintenance at their businesses. This demographic trend of late-life laboring is, according to demographers, visible across lower-income Latin American countries where adults beyond sixty-five continue in the labor force (Lanza Queiroz 2017, p. 133). Men do handiwork, street vending, food delivery, farming, and the like, supplementing household income and meager state pensions. Women sell goods alongside the street, at bus stops, and in marketplaces, and also do door-to-door deliveries in ways unlikely for people of a younger age. They prepare food; sell fruits, vegetables, and grains; and offer trinkets and clothing; in addition to doing housework and caring for children. Older adults, too, act as marketplace lookouts by informing vendors of bad actors, look after children while parents are busy selling wares, or advertise via emotive address to passing customers, 
thereby contributing to stand upkeep. As retirement age increases and social security pensions decrease for the qualified, informal sector laborers are forced to work into older adulthood to ensure their own social reproduction. Older individuals, including neighbors and relatives, contribute to family earnings by navigating a labor market that openly discriminates against old age laborers and that, in fact, prefers workers who are no older than thirty-five (Henríquez 2018). The erosion of social welfare for older Salvadorans, coupled with an imperiled social security system, has made retirement unattainable. Instead, older adults must extend laboring activity into their retirement years. Coming demographic changes will undoubtedly worsen care access for aging people and complicate these already-fragile practices for survival (Avalos 2019).

Older adulthood, in El Salvador, is not a lucrative or glorious way of life. As a 2004 report put it, "In Latin America ... being old is almost synonymous with being poor" (González 2004). Late-stage impoverishment results from the state's divestment of social services, slashing of economic and housing support, and effectively abandoning older adults to fend for themselves. Generally, older Salvadorans live on a few dollars a day and remain trapped in cycles of poverty, realities that push them into the labor market at an advanced age, prompting late life pursuit of "quality of life" survival strategies (Rodríguez 2019). For older persons unable to secure stable work, many become unhoused, turning to panhandling throughout the city, moving about urban space on poorly maintained public transportation. Destitute older adults living in conditions of neglect are abundant in the streets of San Salvador's densely populated zones, where a vital minimum - health and life satisfaction-is attained despite precarity. To curb this growing phenomenon, states will need to develop programs to serve this increasing vulnerable group. One such move might be government investment in the refurbishment of existing state-provided housing for aging persons, in addition to reimagining the national pension system (Mesa-Lago 2019). In El Salvador today, where only $20 \%$ of people over sixty years of age receive a pension, a shift to full coverage is unlikely to happen anytime soon (Huenchuan 2018). Alarming food insecurity, water shortages, and community underdevelopment as a generalized crisis also affects older Salvadorans in compounded ways. The funneling of older adults into a precarious post-retirement tends to propel older Salvadorans back into the labor force, even if they do receive a meager state subsidy. An older adult and San Martín resident, for example, sells food to people in San Salvador, as well as in her neighborhood, to remedy income needs. Others take on the tasks of home upkeep or even do domestic work for neighbors. On the other hand, for transnational retirees that move to El Salvador after laboring in the United States, their return is supported by US social security benefits, perhaps a small savings, or continued family remittances. This subsect of older Salvadorans may, indeed, live old age — attaining a dignified vital minimum — without the need to reenter the in/formal labor force.

Economic necessity, inevitably, pushes a sizable subset of Salvadorans to migrate outward. Mother caregivers and parents, reports show, routinely leave places like El Salvador to seek opportunity outside of the home country-many times without their children. This process of disconnection gives way to transnational family formation and leaves older persons — such as grandmothers, aunts, even older siblings— to step 
into guardian roles for parentless children and dependents left behind, though this varies (Abrego 2014, pp. 118, 124). In an important intergenerational study focused on Nicaraguan transnational families, anthropologist Kristin Yarris (2017) demonstrates how grandmothers take on the responsibilities of the absent migrant mother and assume the task of raising, educating, and fostering youth upon mother departure. Older adult work in El Salvador, as in neighboring Nicaragua, is multigenerational care work. This common familial practice further underscores the centrality of older adults to the well-being of transnational care economies, to local homemaking, and to family welfare in remittance-reliant countries. Transnational return too, is integral to this circulation of care, where the presence of older persons, retirees, within origin communities can establish closer relations to in-country family and longtime friends, encouraging aged Salvadorans to strengthen familial and extrafamilial connections, offering interpersonal and emotional labor to facilitate ties across space and time.

\section{Transnational vital minimums}

For older age migrants living in places such as the US, where a dignified end-oflife is repeatedly viewed as the resort-like retirement community, turning toward transnational return is not a desirable outcome. The presumed objective of US retirement, as a generalized assumption, is that children, or grandchildren, will be the ones to benefit from their life-long accumulations: investments, properties, labor. This amassing of modest capital is thought to also be a pot from which to subsidize late life comforts. However, economic variation-labor experiences, family specificity, and health - throughout the life-course inevitably shifts financial outcomes and modifies older age decision-making. Older Salvadorans, specifically relatives and family friends, shared their thoughts on this dynamic, noting how increasingly their children and loved ones face their own economic stress as a result of skyrocketing US costs of living. This, in turn, limits relatives' ability to offer care, pay for retirement arrangements, or even save or prepare for emergency expenses.

Leaving for the origin country is a way for older adults to lessen the economic burden for their own families. It is a way to anticipate the negative effect of their slowing earning potential on the economics of a family. For returnees, there is a belief that a tranquil third age means reuniting with one's culture and soil, by leaving the destination country behind. This view is furthered by changing US social conditions that intensify inhumane treatment for migrant peoples and their communities, where an inflamed racial animus has material and embodied quality-of-life implications for Latinos and Latin Americans of all ages. Surging anti-immigrant public sentiment under the Trump administration, expectedly, has made US society feel inhospitable, which creates, for those advancing into retirement, a reduction in sensed safety and welcome, prompting further reconsideration of staying in a United States ever more hostile to their presence. This cultural shift instead motivates older adults to opt for retirement in culturally receptive origin countries like El Salvador. This trend is comparable in other countries with established transnational care chains and institutional contexts receptive to retiree return, such as Chile and 
Argentina, though more specific research is needed on transnational aging practices in response to racist mainstreaming, what Mondon and Winter have recently termed an age of "reactionary democracy" (2020). In addition to rising US costs of living and care and other trends that make financial safety nets or nest eggs an unlikely scenario, older adult return has become a late-life option for Salvadoran migrants. Economic stress aside, this practice also raises the question of what constitutes "successful aging," prompting scholars to better specify what driving forces or pull factors are motivating "going home" (Stefansson 2004). Old age return then, offers the possibility of attaining a vital minimum via transnational movement beyond the US, carving out a dignified life elsewhere with the limited means derived from the former.

For some older Salvadorans, like my parents, who attained US citizenship in their time abroad, the decision to leave the United States for a country like El Salvador asks us to contend with the complexity of late life well-being: that voluntarily leaving the United States via retiree repatriation is a way of addressing a set of largely overlooked needs often encapsulated by the common phrase aquí, la vida es muy cara-here, life is too expensive. For older adults, these needs are composed of myriad rationales, personal calculations, and desires. Other decision-making logics, such as family outcomes, will be particular to the migrant or family in question. Comparatively, a neighboring family_acquaintances who have all but relocated to the US Midwest - encouraged their older, differently abled brother to move to El Salvador to afford him specialist in-home care. For my own parents, who lived and worked in Los Angeles, the realities of wage compression, job loss, and unstable employment effectively influenced the economics of our family as they retired-from myself to my siblings, their children, and other dependents- thus making it unrealistic to assume that offering them US-style old age care was part of our financial power at that time. From the rising costs of living in metro areas such as Los Angeles, San Francisco, New York, Chicago, Washington, DC, and other places where Salvadorans have long made community, being "priced out" does not automatically entail a move to the suburbs or to more economically accessible US cities or parts of the country, but might, instead, lead one to uproot from the US altogether. Of course, it bears repeating, return is also dependent on divergent experiences in accumulated life wealth, investment, real estate ownership, social mobility and integration, in the United States, outcomes qualified by the subsequent earning potential of family and relatives. As in the case of the differently abled brother sent to El Salvador to seek affordable health care, the family was motivated to lessen their economic burden while taking advantage of his US government assistance, using it in a place where it might be most useful and cost-effective.

Evidently, the reasons that compel retiree repatriation are, while context-specific and highly dependent on family composition, focused on securing a standard of living increasingly inaccessible. By taking advantage of cost-of-living differences, transnational returnees can delay economic unproductiveness, lessen family resource burden, seek care and restore their social autonomy. For those who hold legal right to US permanency, this decision to live, "against all common sense," in a place consistently listed as the most violent country in the hemisphere exceeds the simple want to expire in their home nation or for some superficial familism (Ruiz 
and Ransford 2012). In many cases, it is also about the economic and social roles available to older adults, about cultural fluencies, as well as subcultures that integrate older persons as productive community members, enabling participation in social groups and forms of neighborhood bonding: from religious meetings to cultural celebrations, sporting events, birthdays, and political rallies to other kinds of local gatherings. This might take the form of autonomy, old age entrepreneurship, or even through integrating older persons in the making of multigenerational and transnationally connected homes, thereby empowering them to purposive space beyond the care facility. Old age return, too, is motivated by expanding social animosity, racism, and ageist stereotyping felt by retirees in US society. Living as racialized subjects in the United States, older adults repatriate to an El Salvador where, while afflicted by insecurity and its ingrained economic contradictions, a sense of belonging and social function remains accessible, away from the felt discriminations that saturate US social life.

\section{Varieties of Salvadoran aging}

What motivations drive retiree decisions to leave the relative safety and quality of life available in the United States? To explain this, Masferrer's concept of the vital minimum, as a theory of needs, offers clues for understanding transnational aging and return. Old age repatriation emerges from within the Salvadoran cultural economy of aging, where returnees pursue forms of well-being and feelings of social usefulness that are no longer possible in a rapidly changing United States. Aging in the US, as I uncovered through conversations with family, locals, and their relatives, repeatedly suggested being unable to afford a loved one's US-based retirement. For older persons and their families, placing their old into lesser arrangements generated anxiety and fear about their possible "humiliation" and "abandonment" into government housing or into spartan living arrangements. Older Salvadorans carry stress about their late-life strategies with regard to how they will sustain themselves as they age out of the US workforce. Taking my own parents as indicators of this minor trend, aging in El Salvador presented material advantages, where things like purchasing power on a US pension made monthly expenses and access to care (even if of lesser quality) more attainable, a moderating of rising health care costs. US retirees, who receive on average approximately $\$ 1,500$ a month, note how costs of housing, utilities, transportation, food, and medicine become workable expenses using a US pension within the Salvadoran economy. For them, the US pension makes possible a dignified, yet still minimal, retirement life in a low-wage, and still largely informal, economy. In contrast to remaining in the United States where, according to median Social Security Administration numbers, an approximate \$1500 (minimum) to even $\$ 3,000$ (maximum) monthly pension has limited use in costly US urban areas or their suburbs where Salvadorans tend to work and live (SSA 2020). Despite its costs, the view among some older Salvadoran migrants, though this depends on age at migration, acculturation, social relationships, language acquisition, and living arrangements, is that growing old past the retirement transition in the United States 
is one of solitude and, in many cases, staying in assisted-living homes or for-profit retirement communities of varying quality, that keeps older people away from relatives, excerpting them from participation in broader society (Harrington and Carrillo 2018).

For retiring returnees with transnational experience, the United States is a stressful location for living one's old age. The characteristics of an intolerant US society make it such that racial difference, inequality, and discrimination may persist, if not increase, in retirement settings. Older adults across the cantons I moved in shared feelings of dread about retirement living. Seeking to avoid this, older adults fear humiliation and difficulty in communicating needs, and reject their infantilization, their being made dependent, within institutionalized care contexts. In one case, another neighborhood family described their older parent who returned after becoming exhausted with US-style senior living and who, upon arrival, began selling specialty foods. Their food-vending business has grown because of its distinct culinary style, yet remains a door-to-door, informal, word-of-mouth service that is frequented by other local older adults and retirees. Thus, in El Salvador, the perception from retiring adults remains that-if necessary-labor opportunities and autonomy might remain available, leveraging community ties and cheap everyday living to lessen total dependency on assisted living. As suggested, transnational return is a life strategy of slowing the process of becoming a family burden, where a vital minimum as described by Masferrer - the basic requirements of a satisfying life-is still realizable in the home country thanks to differences in costs of living and cultural flexibility afforded to those in older adulthood.

For low to middle-income aging Salvadorans in the United States, the "retirement community" is anxiety inducing. Older persons tend to draw on rumors of what constitutes retirement living compared to cultural expectations of aging well (Beyene et al. 2002). Further, old age housing continues to be stigmatized within Salvadoran culture because of stories of widely known disrepair and poor care offered by the infamous Sara Zaldivar asylum, located in San Salvador, a place repeatedly scrutinized for human rights violations, most recently for claims of negligence, death, and infections related to COVID-19. In the twenty-first century, as evidenced by the growing amount of retirement communities, hospices, nursing homes, or hogares de ancianos (elderly housing) of private or religious ownership, the overall need for retirement living has substantially ballooned.

According to an undated document drafted by the administration of Salvador Sánchez Cerén (2014-2019), only two government asylums are run by the state, while private entities number forty-eight and growing (GOES nd). It is also usual that older persons retire in El Salvador's numerous gated communities; this is likely for aging adults who might receive familial remittances or have access to property owned by migrant homeowners. Gated communities are often advertised to the migrant market as a tranquil and safe site for retirement living. Though a variety of care arrangements exist, from sites of total abandonment to privileged assisted living, the institutionalized senior community is perceived to be of a warped sociality, where adult independence is traded for assisted living, though even these feelings toward retirement outcomes remain deeply gendered. In El Salvador, one advantage is that care labor is proffered by an older adult's family (nuclear or extended), which 
enables persons to remain feeling useful. It allows for older adults to hold onto their autonomy by living in close contact with relatives and community members. While this also happens in the United States, the burden of health care, housing, and other emergency costs make this possibility difficult. Nevertheless, these care configurations remain of important psychological and social benefit to older adults that may, as clinical research shows, offset late-life depression (Blazer 2009). For those who have not retired, the changing US political landscape, along with increasing antiimmigrant animus, weighs heavily on older adult decision-making regarding return, prompting some to entertain the idea of aging transnationally prior to formal retirement, if simply to get paperwork in order.

With varying levels of assimilation to the "American way of life," repatriation to El Salvador continues to be an important consideration, even if simply as an option, for US-based Salvadoran retirees. Repatriation is an imagined endpoint of the migrant life cycle, though it may at times prove unrealizable as conditions in Central America complicate effective return. As the vital minimum moves beyond seniors' grasps, retirees must contend with leaving the US and face the reality that possibilities for dignified living in the United States are narrowing, and that widening racial hostilities can, and do, impact quality of life. As the Central American community becomes legible solely through optics of "illegality," "criminality," and "deportability" (De Genova 2002; Coutin 2013), returning to the origin country becomes a concerted strategy to find tranquility and social stability in a low-wage economy with US-earned money and benefits, possibly with US citizenship or resident benefits, while being in a culturally familiar context where racial discomfort is, effectively, left behind. This, of course, contrasts greatly with the retirement prospects of those who only labored in El Salvador, possibly with only irregular remittance support.

What awaits retirement-age Salvadorans who permanently return to the country after working in the United States? Life for retirees in El Salvador is, perceptibly, different from that of other age groups. This is a result of US-retiree-led homes having stable government pensions sent from abroad supported by common cultural practices of older adult care: family-first senior care. For older Salvadorans this is an "aging well" outcome, since they avoid retirement homes and can live distanced from the social patterns of US society that emphasize productivity and selfsufficiency as part of migrant work-life, an aspect of the neoliberalization of old age (Macnicol 2015). For older Salvadorans, life in El Salvador retains qualities of selfsufficiency and self-actualization that seem all but stripped away by a US cultural ageism that discards the old into retirement homes. Indeed, this is an imagined and altogether romantic view of old age living in El Salvador, yet it underscores the latestage need for community, for belonging, and for continued access to forms of selffulfillment, of a different form of old age sociality that contradicts the timeline of aging as infirmity, as a kind of incremental uselessness.

Aware of risks in El Salvador, older adults' sense of security remains paramount. My observations in San Salvador's markets and in local vending spaces in San Martín and Ilopango suggest that seniors are often excerpted from crime and violence, including extortion. Social insecurity notwithstanding, older persons appear tacitly permitted to move through embattled space unencumbered. This reality enables mobility and feelings of, as the persons I spoke to described, a greater sense 
of individual security that contrasts starkly with youth experiences in those same neighborhoods, roads, and public transit. It remains uncommon to read or hear of older, retired persons as victims of gang-related violence or crime, though cases do surface, as the story of seventy-two-year-old Margarita Ramirez reveals. Margarita was forced to leave El Salvador and migrate to Mexico because of death threats on her family by local gangs who sought to extort her thirty-seven-year-old son José (Frederick 2017). Although they do happen, these cases are exceptional. In general terms, older people live almost entirely separate from the commonplace occurrences that make up the routine worlds of a people whose average age is a young 25.8 (UN 2017, p. 36). On an average Salvadoran day, one observes that most people doing neighborhood errands, picking up food, or riding the bus to do local shopping tend to be older persons. In my own bus riding across El Salvador, seeing older adults on public transit emerged as a significant social pattern.

Similarly, at funerals, religious processions, and burials, which happen often-as moments marking public life and popular religiosity-it is generally older people who attend. One account from youth on the outskirts of San Bartolomé Perulapía shared that they fear being identified and singled-out or run the risk of creating problems with local gangs if they appear at events like burials, mass, and related cultural events like community contests, festivals, or even at bars and restaurants with known gang clientele. On the contrary, for older adults, participating in these spaces was culturally expected, a characteristic, habit, even a stereotype, of old age sociality. These dynamics appear to be slowly changing, while the gang problem persists as largely a youth issue wherein the lives of older people seem exempt from the territorial and interpersonal disputes that define gang rivalry. Features of advanced age marks an entire demographic as distinct, with their social rhythms separate from the conflicts, altercations, and policing that exacerbate the gang phenomenon. Old age, in an El Salvador marked by violence, indicates nonaffiliation or neutrality, whereas a profiled youth through middle adulthood continue generating anxiety, suspicion, and fear. In a moment where gangs are no longer visibly distinguishable by tattoos or modes of dress, age has become a quick, flexible, yet important identifier. Circulating images of gangs, victims, reports of child recruitment, and discourses of corruptible youth reinscribe this wide age bracket as a social problem in popular thinking, thus affecting generalized behavior toward it (Cruz 2017; Wolf 2011).

Little remarked in the distinction between youth and old age is how this differentiation entails an opposed form of social profiling and experience. On the youth end, we have the menacing figure of the marero or gang member, an omnipresent and aggressive young person donning a tattooed face and frequently used for political theater, paraded on newspapers, book covers, and documentary film (Zilberg 2011). This diabolic character of Salvadoran imagination, while no longer a widespread aesthetic, remains a repeatedly politicized threat, productive for pushing punitive state efforts, and that also produces a "structure of feeling" linked to and embedded in age specificity. On the contrary, the old are never viewed this way and are instead considered an enfeebled, vulnerable population requiring care, and that is largely churchgoing, economically dependent, and tired. These generalizations, even if misplaced, reinforce the Salvadoran custom of caring for older persons via in-home arrangements that offer culturally appropriate retirement living. The present "gang 
conflict"- that social contradiction produced by entrenched inequality and organized abandonment - is largely accepted and narrated as a youth crisis. It is seldom considered applicable to the old, who move in a society otherwise unencumbered by El Salvador's invisible borders, only tangentially affected by the violent logics of street rule. Recognizing and evaluating this qualitative difference in experience is critical for retirees considering late-stage repatriation. The narrative of an out-ofcontrol youth problem serves to, in a sense, quarantine the crisis from older persons, who, as a class, appear not to be a focus or source of tension with respect to insecurity, crime, or generalized suspicion.

\section{Toward a theory of old age need}

The vital minimum concept, here utilized to frame contemporary and transnational aging, or living one's retirement years in El Salvador, suggests we pay special attention to care arrangements that address the dignity and need of older persons in culturally specific ways. By placing Masferrer's notion alongside modern views on "standards of living" or a "living wage," and in dialogue with critical gerontology, we see that aging transnationally for older returnee Salvadorans is, if ordinary, a survival strategy to minimize their expected dependency on both familial networks and the state, to maximize their remaining social autonomy, to seek forms of self-actualization and social reproduction. Though this is not guaranteed, as variability among returnees is inevitable, this late-life objective remains constant. The vital minimum, unlinked from its modernist assumptions and previous appropriations, serves as a metonym for desiring a dignified old age. It can, if elaborated across old age group experiences, offer a working concept for claims-making, as a social barometer, and for grasping the politics of older adulthood, whether of local or migrant origin, in El Salvador. It places well-being at the center of subsistence and belonging, rooted in the need for safety, comfort, and agency. The explanatory power of the vital minimum rests on its capaciousness and elasticity as a concept for attending to the interlocked issues of old age decline. As a conceptual device, it addresses economic dependency and autonomy and offers cultural specificity and language to reorient debate on senior rights and old age advocacy. As an interpretative "care" notion with interdisciplinary reach, the vital minimum draws sharp attention to thinning transnational care arrangements lived by older actors in El Salvador and the United States, in this juncture prompted by economic stress as well as racial hostility.

Most of the literature pertaining to Salvadoran migration accounts for the hardships of living in US society as undocumented or under "temporary protected" statuses, chronicling the experience of capture, detention, and deportation that has spurred the phenomenon of transnational family formation. These studies, which map a range of experiences linked to inclusion/exclusion logics with relation to the destination polity, remain disconnected from aging and care studies. Research on the retirement lives of older people who choose to return to the home nation is largely underexplored, and even more so in the Central American context, where age, disability, and care studies remain limited. This recent small wave of older adult 
return to the isthmus, from "successful" migrants and non-deportees, who return to national territory for personal reasons, mirror past generation approaches to seeking comfortable end-of-life arrangements yet are propelled by distinct contexts and experiences throughout the life course.

Paying concerted attention to the social function of age will undoubtedly spur studies on the worlds, mobilities, and related interdisciplinary topics on varieties of aging, eliciting comparison with the transnational return practices of other migrant communities, or even the long-term effects of prior generations' old age mobilities. Thus, Masferrer's vital minimum, as a metric to approximate well-being, touches on the age-specific dialectics of Salvadoran transnationalism to illustrate how social reality, culturally informed perceptions, and cross-country experiences do influence the criteria and desired location of aging (Landolt et al. 1999). Vis-à-vis life contingencies that perhaps allowed for securing late-life income via citizenship, good fortune, or purchasing property, repatriation is for older members of the Salvadoran diaspora an assured way to attain what Masferrer theorized as the vital minimuman integral form of dignity as an individual and social good-shedding the sharply classed, raced, and ageist realities of US-style older adulthood. To escape this relentless gaze of otherization, more Salvadorans approaching retirement age are weighing the possibility of return, considering the benefit of retiring to communities where the cost of everyday reproduction is markedly less and where something affective and felt, like culture, offers a deep sense of belonging, a proximity to the spaces and lands in which they hope to expire.

Masferrer's thinking on age enables us to reintegrate dignity as an indispensable part of the "vital minimum" concept, adding life stage as central to not only his life philosophy of well-being and maxim, but also to a broader framework for contemporary social analysis. Masferrer's thinking, when read in a twenty-first-century context, suggests that we link the welfare of the aged to a sense of collective security. Older adults, like youth, are indispensable participants to forming stable, multigenerational, and coherent communities. In an El Salvador that is progressively aging, and where older adulthood will soon be the median age, questions of senior well-being will become further central to social agendas moving forward. The demographic processes that prompt transnational return, such as those that propelled my parents, must be connected to the general Salvadoran crisis of care, of plummeting family wages, of the weakening of community-driven support structures. As old age migration studies remind us, age-related mobilities are part of a complex repertoire of transnational survival strategies for mitigating life-course decline. Returns, for Salvadorans, hence function as a quotidian fix for seniors and older adults struggling to secure a dignified end of life, weighing out the discomforts of remaining in the United States. Within the transnational economy that has long imbricated the United States and El Salvador, Salvadorans retiring away from northern capitalist economies will likely have pronounced effect on "care-chains" that extend into Central America. The care arrangements that emerge around older adulthood in El Salvador accordingly demonstrate how community and culture can and often do fill the void of what have, in large part, become market activities that have made transactive the responsibility of old age maintenance (Fraser 2016). 
Across Latin America, in response to demographic shift, solidarity care economies-other forms of vital minimums-have emerged as local efforts to address what both public and private sectors have failed to deliver. Cooperative groups have devised shared living spaces and small-scale caregiving employment opportunities that pool resources and redistribute meager pensions among older adults in their communities. For these demographic and political scenarios fueled by changes in places like the United States, Masferrer's "vital minimum” provides a workable, fruitful theory of dignity, also portable as a care metaphor, a term inviting us to read older adulthood through the prism of good living. Masferrerian thought, limited and at times shortsighted, remains relevant for thinking about the Salvadoran contextthat recovering ideas from the intellectual history of the country can help to examine present-day national and transnational realities, locating the arrhythmias of social life to reveal how comfort and discomfort are experienced through age as an actual structure of feeling (Williams 1986, p. 30). The vital minimum as an analytic offers an interpretative approach, a prism, for sensing how structural inequalities affect aging and impinge on life, work, and recreation. It allows us to glean, if incompletely, how old age precarity is lived, and how the elimination of economic safety nets-for both young and old along the migrant lifecycle-subjects people ever more to the tempos of capitalism's machinery by eroding the structures that support aging well (Masferrer 1971, p. 228). The act of retiree return is, then, for a subset of Salvadorans, positioned to take advantage of changing conditions, a care calculusa survival play that is itself a bid toward a vital minimum - to stave off undignified expiration, forgo racial and economic humiliation, and hold on to a sense of purpose and social worth.

Acknowledgements I would like to thank the viejitos who have spoken to me over the years about their experiences of living in El Salvador and the challenges of return. Special gratitude to my parents, whose retirement process piqued my interest in transnational aging as a lens for social and cultural analysis. I also want to express my warmest gratitude to Mérida M. Rúa, Katynka Z. Martínez, the anonymous reviewers, and to the Latino Studies editorial team for their support, valuable feedback, and suggestions.

\section{References}

Abrego, L. 2014. Sacrificing families: Navigating laws, labor, and love across borders. Palo Alto, CA: Stanford University Press.

Alemán, J. 2017. El anarquismo en El Salvador: Un balance historiográfico. 10 January. https://josal emnh. wordpress.com/2017/01/10/el-anarquismo-en-el-salvador-un-balance-historiografico/. Accessed 13 Dec 2019.

Aparicio, L.A. 2007. Alberto Masferrer: Pedagogo-Politico. San Salvador: Universidad Peedagógica de El Salvador.

Aranco, N., M. Stampini, P. Ibarrarán, and N. Medellín. 2018. Panorama de envejecimiento y dependencia en América Latina y el Caribe. January. Banco Interamericano de Desarollo. https://doi.org/10. 18235/0000984.

Associated Press. 2016. El Salvador: veteranos de guerra exigen indemnizaciones. AP News. 29 April. https://apnews.com/a5e01b1ce52a4beda87701bb49191357.

Avalos, C. 2019. The challenges of an aging society: The case of El Salvador. ReVista: Harvard review of Latin America. Cambridge, MA: David Rockefeller Center for Latin American Studies. 
Beyene, Y., G. Becker, and N. Mayen. 2002. Perception of aging and sense of well-being among Latino elderly. Journal of Cross-Cultural Gerontology 17: 155-172.

Blazer, D.G. 2009. Depression in late life: Review and commentary. Geriatric Psychiatry 7 (1): 118-136.

Briggs, L. 2003. Mother, child, race, nation: The visual iconography of rescue and the politics of transnational and transracial adoption. Gender and History 15 (2): 179-200.

Casaús Arzú, M. E. 2009a. Aspectos del legado de Masferrer al pensamiento centroamericano.El Faro, 8 July. http://archivo.elfaro.net/secciones/academico/20090706/academico1.asp.

Casaús Arzú, M.E. 2009b. El binomio degeneración-regeneración en las élites intelectuales espiritualistas de principios del siglo XX en Centroamérica. Revista Complutense De Historia De América 35: 109-133.

Casaús Arzú, M. E. 2011. El vitalismo teosófico como discurso alternativo de las élites intelectuales centroamericanas en las décadas de 1920 y 1930. Principales difusores: Profirio Barba Jacob, Carlos Wyld Ospina y Alberto Masferrer. Revista de Estudios Históricos de la Masonería Latinoamericana y Caribeña 3 (1): 81-120.

Casaús Arzú, M. E., and R. Fuentes. 2012. El libro de la Vida de Alberto Masferrer y otros escritos vitalistas: Edición crítica de la obra teosófico-vitalista (1927-1932). Guatemala: F\&G Editores.

Ching, E. 2014. Authoritarian El Salvador: Politics and the origins of the military regimes, 18801940. Notre Dame, IN: University of Notre Dame Press.

Córdova, R., D. Burgos, V. Tablas, and F. Rodríguez. 2010. Las tendencias demográficas de la población adulta mayor y sus implicaciones para las polítcas públicas en materia de seguridad social. San Salvador: FundaUngo.

Coutin, S.B. 2013. Place and presence within Salvadoran deportees' narratives of removal. Childhood 20 (3): 323-336.

Cruz, J. M. 2017. Central American gangs like MS-13 were born out of failed anti-crime policies. The Conversation, 8 May. https://theconversation.com/central-american-gangs-like-ms-13-wereborn-out-of-failed-anti-crime-policies-76554.

Cuéllar, J.E. 2018. Elimination/deracination: Colonial terror, La Matanza, and the 1930s race laws in El Salvador. American Indian Culture and Research Journal 42 (2): 39-56.

De Genova, N. 2002. Migrant "illegality" and deportability in everyday life. Annual Review of Anthropology 31: 419-447.

Franco, J. 2013. Cruel modernity. Durham, NC: Duke University Press.

Fraser, N. 2016. Contradictions of capital and care. New Left Review 100: 99-117.

Frederick, J. 2017. Elderly and on the run from El Salvador's street gangs. United Nations Refugee Agency (UNHCR). 7 April. https://www.unhcr.org/en-us/news/stories/2017/4/58e4e5c24/elder ly-run-el-salvadors-street-gangs.html.

GOES (Gobierno de El Salvador). n.d. Establecimientos públicos y privados de atención a personas adultas mayores. https://www.transparencia.gob.sv/institutions/capres/documents/255000/downl oad.

González, G. 2004. America Latina: Cada vez más viejos y pobres. Inter Press Service, 12 April. http://www.ipsnoticias.net/2004/04/america-latina-cada-vez-mas-viejos-y-pobres/.

Grandin, G. 2000. The blood of Guatemala: A history of race and nation. Durham, NC: Duke University Press.

Guerra Reyes, V.M. 2014. Alberto Masferrer y su quehacer intelectual: Una búsqueda sincera de la justicia social. San Salvador: Editorial Universidad Don Bosco.

Guerra Reyes, V.M. 2015. Alberto Masferrer y la Educación Vitalista en El Salvador. Día-Logos 13: 17-18.

Harrington, C., and H. Carrillo. 2018. Nursing facilities, staffing, residents and facility deficiencies 2009 through 2016. Washington, DC: Kaiser Family Foundation.

Henríquez, K. 2018. La participación del adulto mayor en el área laboral. El Diario de Hoy, 25 August. https://www.elsalvador.com/noticias/la-participacion-del-adulto-mayor-en-el-area-labor al/512516/2018/.

Huenchuan, S. 2018. Envejecimiento, personas mayores y Agenda 2030 para el Desarollo Sostenible: Perspectiva regional y de derechos humanos. Libros de CEPAL, No. 154. Santiago: CEPAL.

Introvigne, M. 2016. "Theosophical" artistic networks in the Americas, 1920-1950. Nova Religio: THe Journal of Alternative and Emergent Religions 19 (4): 33-56.

Landolt, P., L. Autler, and S. Baires. 1999. From Hermano Lejano to Hermano Mayor: The dialectics of Salvadoran transnationalism. Ethnic and Racial Studies 22 (2): 290-315. 
Lanza Queiroz, B. 2017. Public pensions, economic development, and the labor force participation of older adults in Latin America in 1990-2010. International Journal of Population Studies 3 (1): 121-137.

Lara-Martínez, R. 2011. Política de la Cultura del Martinato. San Salvador: Editorial Universidad Don Bosco.

Lara-Martínez, R. 2017. "Todos los indios son blancos," todas las mujeres, "señoras de la belleza en la casa”: Del racismo y el sexismo en Alberto Masferrer. In Masculinidades Salvadoreñas: Cuerpo, Raza, Etnia, 127-134. San Salvador: Fundación AccesArte.

Levenson, D. 2013. Adiós Niño: The gangs of Guatemala City and the politics of death. Durham, NC: Duke University Press.

Lopez Vallecillos, I. 1968. Masferrer, reformador social. Cultura: Revista del Ministerio de Educación 47:15-20.

Macnicol, J. 2015. Neoliberalising old age. London: Cambridge University Press.

Marroquín, D. 2015. Medicina Legal estima que 2015 cerrará con más 6,600 homicidos. El Diario de Hoy, 12 December. https://historico.elsalvador.com/historico/172447/medicina-legal-estima-que2015-cerrara-con-mas-6600-homicidios.html.

Masferrer, A. 1947. ¿Que debemos saber?: Cartas a un obrero. San Salvador: Imprenta Funes.

Masferrer, A. 1968. Niñerias. San Salvador: Ministerio de Educación/Dirección de Publicaciones.

Masferrer, A. 1971. Maquinas y hombres. Obras escogidas. San Salvador: Universidad de El Salvador.

Masferrer, A. 1996. El Mínimum Vital [1929]. In Ensayos, 61-83. San Salvador: Ministerio de Educación/Dirección de Publicaciones e Impresos.

Mesa-Lago, C. 2019. Aging and pension reforms: A look at Latin America. ReVista: Harvard Review of Latin America. Cambridge, MA: David Rockefeller Center for Latin American Studies.

Mondon, A., and A. Winter. 2020. Reactionary democracy: How racism and the populist far right became mainstream. New York: Verso.

Morris, R., and S.A. Bass. 1986. The elderly as a surplus people: Is there a role for higher education? The Gerontologist 26 (1): 12-18.

Pacheco, M. 2019. El gobierno aumentará a \$100 la pension de veteranos. La Prensa Gráfica, 18 October. https://www.laprensagrafica.com/elsalvador/El-gobierno-aumentara-a-100-la-pension-de-veter anos-20191017-0737.html.

Park, H. 2014. Q. and A.: Children at the border. New York Times, 21 October. https://www.nytimes.com/ interactive/2014/07/15/us/questions-about-the-border-kids.html.

Racine, K. 1997. Alberto Masferrer and the vital minimum: The life and thought of a Salvadoran journalist, 1868-1932. The Americas 54 (2): 209-237.

Rodríguez, M. 2019. Desprotección, la realidad de las personas adultas mayores en El Salvador. ARPAS, 19 December. https://arpas.org.sv/2019/12/desproteccion-la-realidad-de-las-personas-adultas-mayor es-en-el-salvador/.

Ruiz, M.E., and E. Ransford. 2012. Latino elders reframing Familismo: Implications for health and caregiving support. Journal of Cultural Diversity 19 (2): 50-57.

Social Security Administration (SSA). 2020. Fact sheet: Social security. Social Security Administration. https://www.ssa.gov/news/press/factsheets/colafacts2020.pdf

Stefansson, A.H. 2004. Homecomings to the future: From diasporic mythographies to social projects of return. In Homecomings: unsettling paths of return, ed. F. Markowitz and A.H. Stefansson, 2-20. Lanham, MD: Lexington Books.

Tablas, V. 2012. La Población Adulta Mayor en El Salvador: Indicadores Socioeconómicos y Demográficos a Nivel Municipal. San Salvador: FundaUngo.

Thelen, T., and C. Coe. 2017. Political belonging through elderly care: Temporalities. Representations and mutuality. Anthropological Theory 19 (2): 279-299.

UN (United Nations). 2017. World population ageing 2017: Highlights. New York: United Nations.

Villalona, C. 2005. La privatización de las pensiones: otro negocio redondo. San Salvador: Asociación Equipo Maíz.

Wiegink, N., and R. Sprenkels. 2020. Beyond reintegration: War Veteranship in Mozambique and El Salvador. Development and Change. https://doi.org/10.1111/dech.12576.

Williams, R. 1986. The uses of cultural theory. New Left Review 158 (1): 19-31.

Wolf, S. 2011. Living and dying for the crazy life: Exploring documentary representations of the Central American Maras. Revista Centroamericana De Ciencias Sociales 8 (2): 23-52.

Wood, E.J. 2003. Insurgent collective action and civil war in El Salvador. Cambridge, UK: Cambridge University Press. 
Yarris, K. 2017. Care across generations: Solidarity and sacrifice in transnational families. Palo Alto, CA: Stanford University Press.

Yashar, D. 2018. Homicidal ecologies: Illicit economies and complicit states in Latin America. Cambridge, UK: Cambridge University Press.

Zilberg, E. 2011. Space of detention: The making of a transnational gang crisis between Los Angeles and San Salvador. Durham, NC: Duke University Press.

Publisher's Note Springer Nature remains neutral with regard to jurisdictional claims in published maps and institutional affiliations.

Jorge E. Cuéllar is Mellon Faculty Fellow and assistant professor in Latin American, Latino and Caribbean studies at Dartmouth College. Cuéllar is an interdisciplinary scholar whose research focuses on the politics of everyday life in modern Central America. He is currently working on his first book, a multisited study on the politics of life and death in contemporary El Salvador. 